\title{
MERGERS, STATION ENTRY, AND PROGRAMMING VARIETY IN RADIO BROADCASTING
}

\author{
Steven T. Berry \\ Joel Waldfogel \\ Working Paper 7080 \\ http://www.nber.org/papers/w7080 \\ NATIONAL BUREAU OF ECONOMIC RESEARCH \\ 1050 Massachusetts Avenue \\ Cambridge, MA 02138 \\ April 1999
}

We thank Yun-Sug Baik and Yu Li for assistance in assembling the dataset used in the study. Seminar participants at the 1998 AEA meetings in Chicago, the Carnegie Mellon/Pitt joint applied economics seminar, and Wharton provided helpful comments on an earlier draft. We are responsible for any errors. The views expressed in this paper are those of the authors and do not reflect those of the National Bureau of Economic Research.

(1) 1999 by Steven T. Berry and Joel Waldfogel. All rights reserved. Short sections of text, not to exceed two paragraphs, may be quoted without explicit permission provided that full credit, including ${ }^{\circledR}$ notice, is given to the source. 
Mergers, Station Entry, and Programming

Variety in Radio Broadcasting

Steven T. Berry and Joel Waldfogel

NBER Working Paper No. 7080

April 1999

JEL No. L1, L8

\section{ABSTRACT}

Free entry into markets with decreasing average costs and differentiated products can result in an inefficient number of firms and suboptimal product variety. Because new firms and products draw their customers in part from existing products, concentration can affect incentives to enter as well as how to position products. This paper examines how product variety in the radio industry is affected by changes in ownership structure. While it is in general difficult to measure the effect of concentration on other factors such as the number of products and the extent of product variety, the 1996 Telecommunications Act substantially relaxed local radio ownership restrictions, giving rise to a major and exogenous consolidation wave. Between 1993 and 1997 the average Herfindahl index in major US media markets increased by almost 65 percent. Using a panel data set on 243 U.S. radio broadcast markets in 1993 and 1997, we find that concentration reduces entry and increases product variety. Our results are consistent with spatial preemption. Jointly owned stations broadcasting from the same market are more likely than unrelated stations - and more likely than jointly owned stations in different markets - to broadcast in similar formats.

Steven T. Berry

Department of Economics

Yale University

Box 208264

37 Hillhouse Ave.

New Haven, CT 06520-8264

and NBER

steve.berry@yale.edu
Joel Waldfogel

Public Policy and Management

The Wharton School

University of Pennsylvania

3100 Steinberg-Dietrich Hall

Philadelphia, PA 19104-6372

and NBER

waldfogj@wharton.upenn.edu 
It is well known that free entry into markets with decreasing average costs can result in an inefficient number of firms. ${ }^{1}$ The possibility of inefficient entry into radio broadcasting has been discussed for decades (see Steiner, 1952). ${ }^{2}$ Markets for differentiated products are prone to fail to deliver optimal product variety as well. ${ }^{3}$

Ownership concentration has the potential to affect both of these problems. Because new firms and products draw their customers in part from existing products, concentration can affect incentives to enter as well as how to position products. As a result, while mergers that increase concentration generally raise prices, they may also mitigate (or worsen) other distortions associated with the number of products and the extent of variety.

In this paper we consider how product variety in the radio industry is affected by changes in ownership structure. Because market structure is the endogenous outcome of a competitive process, it is in general difficult to measure the effect of concentration on other factors such as the number of products and the extent of product variety. ${ }^{4}$ However, recent changes in radio station ownership rules have given rise to large exogenous increases in concentration. The Telecommunications Act of 1996 substantially relaxed local radio ownership restrictions, prompting a major wave of consolidation in the industry. Between 1993 and 1997 the average Herfindahl index across 243 major media markets increased from 1272 to 2096, or by almost 65 percent. This substantial - and

\footnotetext{
${ }^{1}$ See Mankiw and Whinston (1984).

${ }^{2}$ Recent empirical evidence (Berry and Waldfogel, 1996) shows that free entry produces far more firms than would optimally produce advertising (i.e. ignoring benefits to listeners).

${ }^{3}$ See Spence (1976), Dixit and Stiglitz (1977), Lancaster (1979).

${ }^{4}$ One study attempting to do so is Alexander (1997), who documents the relationship between a measure of product variety and ownership concentration in the music recording industry.
} 
exogenous - growth in ownership concentration makes it possible to measure the effect of ownership concentration on entry and product variety. ${ }^{5}$

This paper proceeds in 5 sections. Section 1 outlines the possible theoretical relationship between ownership and product variety and then presents background information on ownership rules in radio broadcasting. Section 2 describes our data. Section 3 presents our empirical strategy. Section 4 contains estimation results. Using a panel data set on 243 U.S. radio broadcast markets in 1993 and 1997, we find that concentration reduces entry and increases product variety. Section 5 considers possible explanations for the results. We find evidence consistent with spatial preemption. Jointly owned stations broadcasting from the same market are more likely than unrelated stations (and more likely than jointly owned statations in different markets) to broadcast in similar formats. A brief conclusion follows.

\section{Background}

\section{Concentration and the Incentives to Operate and Position Stations}

Concentration can affect the incentives of owners to operate stations, as well as their incentives about where to locate new stations in product space (i.e. which formats a multi-station firm will jointly operate). Here we briefly outline some incentives facing radio station owners.

The possible effects of mergers on incentives to operate stations and offer variety are suggested by a comparison of new entrant and incumbent incentives. When a firm opens a new station, it draws listeners from both "business stealing" (diverting listeners

\footnotetext{
${ }^{5}$ Also worthy of study is the effect of increased concentration on advertising prices. For lack of data we
} 
from existing stations) and market expansion (attracting new listeners to radio). While a non-incumbent firm has an incentive to operate a station if it attracts enough listeners (and therefore advertisers) to cover its costs, an incumbent benefits from adding a station only if the new station's revenue, net of business diverted from its existing stations, covers new station costs. The extent of business stealing as opposed to market expansion engendered by a new station depends on the station's programming format, in relation to existing stations' formats.

These considerations motivate three questions. First, does an increase in concentration reduce the number of products (stations)? Intuition is clear in one extreme hypothetical case: A monopolist, with an exclusive right to operate stations, would close duplicative stations, reducing the number of available stations. However, with free entry, profitable niches will be filled by other firms, undermining the attractiveness of closing stations. ${ }^{6}$ Given increased concentration - albeit short of pure hypothetical monopoly the effect on the number of stations is not obvious a priori. Hence, we examine it empirically.

Second, does increased concentration affect available programming variety? By changing incentives about where to enter, concentration can affect variety. If competitors would enter to fill profitable niches, greater concentration might affect the tendency for firms to offer stations that are close substitutes for their existing offerings. Suppose that a market can support two stations in a format. If the stations become jointly owned and the owner withdraws one station (perhaps moving it to a distinct format), this opens a niche

\footnotetext{
put aside this question in the present study.

${ }^{6}$ Even without free entry, if existing stations can change formats, then viable niches may be attractive to format-switchers.
} 
for a competitor. On the other hand, if the owner stands pat with two identical stations, she steals substantial business from herself. A possible strategy for the merged firm, balancing business stealing and preemptive concerns, is to operate the stations in nearby formats. This would tend to increase the available number of formats. This leads to a third empirical question: are jointly owned stations more likely than unrelated stations to operate in similar formats?

The effects of increased concentration can depend on competitor responses in complex ways. For example, the preemption argument above, while intuitive, may or may not survive in equilibrium, depending on fine distinctions in assumptions. Schmalensee's (1978) result on spatial preemption, that incumbents will crowd the space with products, contrasts with Judd's (1985) critique based on different assumptions about entry. ${ }^{7}$

A formal model of product choice in the radio industry would need to include owners' choices about how many stations to operate, as well as the programming formats at each of their stations. The dimension of an owner's choice set is quite large: if there are 40 distinct programming formats, then in a market where a firm can operate up to eight stations, the number of options in the choice set is the combinatoric,
$\left(\begin{array}{c}40 \\ 8\end{array}\right)$
This very-large dimensional choice problem for the firm must then be embedded in an equilibrium involving all firms in the market. It is not difficult to construct low-

\footnotetext{
${ }^{7}$ Judd's argument in turn depends on the ability of an entrant to offer an exactly identical product, setting off a fierce Bertrand price war. Bonnano (1987) considers a simple equilibrium model of multi-product firms. Presumably because general results are scarce, the model is a worked-out example in a simple Hotelling-style framework. Bonnano finds, for some parameter values, that the firm facing an entry threat will move its products apart rather than proliferating products, as in Schmalensee, to deter entry. Of course, the firm cannot spread the products too far, or it will open up entry possibilities in "the middle" of the product space.
} 
dimensional examples in which no equilibria exist, or in which there are multiple equilibria. The theoretical literature on oligopolistic, multi-product firms facing an entry threat is not very rich, probably because the problem is so difficult. Sutton (1991) points out that in such a situation there may be no pure-strategy equilibrium and, when some equilibrium exists, there may be a large number of plausible equilibria. ${ }^{8}$ Therefore, it is difficult to make clear theoretical predictions about what would happen if the rules governing multiproduct firms were to change. ${ }^{9}$ Our approach in this paper is to obtain qualitative empirical results that may guide more detailed subsequent modeling.

Descriptive empirical results may guide theory toward appropriate models.

\section{Background: the 1996 Telecommunications Act and Radio}

Prior to the Telecommunications Act of 1996, the FCC's "radio contour overlap rule" defined the limits of local commercial radio ownership. This rule limited the number of jointly owned stations in a local market to no more than 3 or 4 stations, depending on the size of the market:

"[The FCC] permits ownership of up to three commercial radio stations, no more than two of which may be in the same service, in radio markets with 14 or fewer stations, provided that the owned stations, if other than a single AM and FM station combination, represent less than 50 percent of the stations in the market; in markets with 15 or more commercial radio stations, ownership of up to two AM and two FM commercial radio stations is generally permitted if the combined audience share of the commonly owned stations does not exceed 25 percent in the market."10

\footnotetext{
${ }^{8}$ Indeed there may not be a unique equilibrium in simple models with multiple types (i.e. multiple radio formats) of single product firms. See Mazzeo (1998) for examples.

${ }^{9}$ Some authors are able to derive equilibrium predictions but only at the cost of restrictive demand functions that may not be appropriate to the radio industry. See, for example, Anderson, DePalma, and Thisse (1992).

${ }^{10}$ FCC Public Notice 96-60. This is also the source of the rule in the next paragraph.
} 
The Telecommunications Act of 1996 (Section 202(b)(1)) directed the FCC to revise the permissible number of commonly-owned commercial radio stations in a local radio market as in the following table.

1996 Telecommunications Act Restrictions on Local Joint Ownership of Radio Stations

\begin{tabular}{ccc}
\hline $\begin{array}{c}\text { Size of Market } \\
\text { \# of Stations) }\end{array}$ & $\begin{array}{c}\text { Max \# of Jointly } \\
\text { Owned Stations }\end{array}$ & $\begin{array}{c}\text { Limit on \# in } \\
\text { Same Service } \\
\text { (AM or FM) }\end{array}$ \\
\hline \hline $45+$ & 8 & 5 \\
$30-44$ & 7 & 4 \\
$15-29$ & 6 & 4 \\
$0-14^{11}$ & 5 & 3 \\
\hline
\end{tabular}

Further, nationwide limits on the total number of stations that could be jointly owned were entirely eliminated (the previous limit was 20 AM and 20 FM.)

The Department of Justice can still review cases and has recently opposed some (otherwise legal) mergers on the grounds that they would potentially raise prices to advertisers (see Klein, 1997). However, it is not clear that the DOJ can oppose mergers on the grounds of product variety; after all there is no "price" paid by the listeners in any case.

Since the passage of the Telecom Act, numerous press reports have documented the growing concentration in the industry, both at the national and local level. The FCC approved transfers of almost 4,000 radio stations in 1996 and some proposed mergers

\footnotetext{
${ }^{11}$ In any case, no one may own more than 50 percent of the stations.
} 
would create nationwide joint ownership of up to 463 stations (compared to the previous limit of 20 AM and 20 FM.) $)^{12}$

The structure of the policy change generates a "natural experiment": because of differing ownership limits by market size, the extent of increased concentration differs across market size. Because the differing limits are determined by policy rather than by the actors themselves, the reason for the differing increases in concentration are exogenous. In other words, the policy change provides a source of exogenous variation, with different-sized markets - with their differently changed ownership limits - providing implicit controls for one another.

\section{Data and Variety Measures}

\section{Data}

The data set used in this study covers commercial stations in 243 U.S. markets in 1993 and $1997 .^{13}$ We observe each station's audience, owner identity, and programming format. Our measure of listening is average quarter hour $(\mathrm{AQH})$ listening, the number of persons listening for at least five minutes during an average quarter hour period. The data for this study are drawn from two sources, James Duncan's American Radio Spring issues for 1993 and 1997, as well as Arbitron's Radio USA, Spring 1993 and Spring 1997. The underlying dataset covers 5,111 commercial stations in 1993 and 5,869 in $1997 .{ }^{14}$

\footnotetext{
${ }^{12}$ See Ness (1997) and Myerson (1998).

${ }^{13}$ Noncommercial stations account for a very small fraction of radio listening. See Berry and Waldfogel (1996).

${ }^{14}$ Note that because each station may be received in more than one market, a "station" is actually a market-station pair. For example, WCBS-AM, based in New York City, is also received in Bridgeport, CT and numerous other markets.
} 
We compute measures of ownership concentration, available programming variety, and the number of available stations at the market level for much of the analysis.

Duncan classifies stations into many varieties according to programming format. We propose to measure programming variety using the number of formats available in a market, as well as simple variants thereof. It is useful to discuss Duncan's classification scheme, as well as our adaptation of it. In 1993 Duncan classified stations into a total of 43 formats. In 1997, he reports 46 formats. Because the increase in the number of reported formats over time may result from both more precise reporting and the appearance of new formats, we do not view the number of available formats as an absolute measure of product variety over time. Instead, we propose to use measures based on the relative change in the number of formats over time. In particular, we will ask how available format diversity changes, across markets, with changes in ownership concentration.

Table 1 shows the distribution of stations across formats for the two years. ${ }^{15}$ By far the most common station format in both years is country music, which accounts for about 14 percent of stations in each year. Between 1993 and 1997 subtler distinctions emerge among formats. For example, 8.51 percent of stations are classified as adult contemporary (AC) in 1993, while in 1993 only a handful of stations are jointly classified as adult contemporary and something else, such as "adult contemporary/contemporary hit radio"(AC/CHR). In 1997, by contrast, the share of pure AC stations has declined to 6.61

\footnotetext{
${ }^{15}$ Our classification of 54 formats groups together formats that are inadvertently coded differently by Duncan. For example, the "urban contemporary hit radio" format is sometimes coded as CHR/U and sometimes U/CHR. We group these together. Similarly, mis-spellings are grouped where they obviously belong. Finally, we do not treat changes in Duncan's scheme as true changes in format: Duncan classifies
} 
percent, while the share of $\mathrm{AC} / \mathrm{CHR}$ stations has risen from 0.18 percent to 2.01 percent. Similar forces are at work with hybrids of album oriented rock (AOR), CHR, and blacktargeted formats.

Because there are substantial asymmetries in listeners across stations within each market, the actual number of stations may, ironically, provide a poor measure of the effective number of stations in the market. To see this, compare the following two situations: a) two stations with equal numbers of listeners; b) two stations, one with 90 percent, the other with ten percent, of listeners. In the second circumstance there are arguably fewer effective stations, and we would like a measure of stations reflecting that. One natural candidate is the reciprocal of the station listening HHI, or $1 / \sum_{i=1}^{N} s_{i}^{2}$, where $s_{i}$ is the share of radio listeners (in a market) choosing station $i$. We term this the station "number equivalent." With symmetry it simplifies to the number of stations. Otherwise, it is smaller than the number of stations, $N$. We also calculate owner and format number equivalents, where $s_{i}$ is reinterpreted as the share of listeners in the local market choosing stations either owned by the same entity or broadcasting the same programming format.

Table 2 presents some characteristics of the sample at the market level, including measures of the number of stations, owners, and formats. In 1993 the number of stations averaged 21.3 per market, which increased by 15 percent to 24.5 in 1997 . In equivalent terms the number of stations rose from 11.5 to 13.7 , or by almost 20 percent. The 
relaxation of ownership limits under the 1996 Telecom Act is clearly evident in table 2: the average number of owners per market fell by 20 percent over this period, even more (by 40 percent) when measured in equivalent terms. Similarly, the average concentration, as measured by the HHI, increases by nearly 65 percent, from 1272 in 1993 to 2096 in 1997. The growth in formats suggested in table 1 appears in the city averages in table 2 as well. The average number of formats available in a market grows by almost a third, from 11.5 to 14.8 (from 6.9 to 8.9 , in equivalent terms).

Ownership HHIs, as well as patterns over time, vary by size of market. Ownership concentration is greater, at all points in time, in small markets than in larger markets. This is certainly what one would expect, given than smaller markets support fewer stations than larger markets. In 1993 the HHI stood at 1775 in markets in the smallest quartile (averaging 113,900 in 1997 population), 1236 in the second quartile (230,600), 1111 in the third quartile $(437,100)$, and 947 in the top quartile $(2,084,500)$, where quartiles are determined by 1997 population. Between 1993 and 1997 the HHI increased substantially in all quartiles, but it increased proportionally more in larger markets (by 41.5 percent in the smallest quartile, by roughly 70 percent in the middle quartiles, and by 95 percent in the top quartile). That the change in concentration differs across markets of different sizes is not surprising given that the 1996 Telecom Act changed ownership limits differently by market size. Even after these changes, concentration remains substantially higher in smaller markets $(1997 \mathrm{HHI}=2512$ in the smallest quartile and 1847 in the largest markets).

together as "Big Band/Nostalgia." 


\section{Formats and Available Variety}

We rely heavily in this study on numbers of industry-reported formats as a measure of product variety. Because these are subjective designations, one might worry whether they actually reflect meaningful differences in programming. Given our reliance on measures of variety based on format designations, it is important for us to explore their meaning. This section discusses the relationship between reported programming formats and some limited but detailed information about station programming.

Before exploring this question, we first consider how one might ideally measure the amount of programming variety in a market. Suppose there are $T$ distinct items of programming (which, for most formats, one could think of as "songs"). We can index these songs from 1 to $T$. Each station chooses whether to play each song and, if so, how frequently. Thus, each station's programming decision can be summarized by a vector of $n_{k}$ 's showing how many times the station plays song $k$, say, per week. ${ }^{16}$ If we sum $n$ across stations in a market, we obtain a vector showing the distribution of airplay across songs. We could calculate variety as the HHI based on song shares of total music played. If different stations play a different mix of songs, the HHI of the sum of the stations will be smaller (reflecting less song concentration) than the song HHI for each station.

Unfortunately, we do not in general have detailed playlist data at the station level. Instead, we have lists of the top 30 songs, by format, for a particular week (Feb. 27, 1998), according to airplay. Detailed playlist data that we have obtained for one format (alternative rock, also known as "album oriented rock/new rock," or AOR/NR) indicate that the top 30 songs in that format account for 60.0 percent of songs played during the 
week. ${ }^{17}$ This suggests that top 30 information reflects the majority of music aired. With top 30 data for multiple formats, we can examine the extent to which songs frequently aired on stations in one format are also frequently aired on stations in other formats. The top 30 overlap information is both interesting in its own right - as a reflection of our measures of variety - and useful for assessing owners' location of stations in product space. We address the latter question below, in section 5.

The top 30 data are reported by Radio \& Records magazine, at their website. ${ }^{18}$ These lists are reported for 12 separate formats, which do not all map directly into Duncan formats. The $12 \mathrm{R} \& \mathrm{R}$ formats (which we term the "R\&R12") are: Active Rock, Adult Alternative, Adult Contemporary, Alternative, Hot Adult Contemporary, Top 40 (Pop), Top 40 (Rhythmic), Country, Jazz/New Adult Contemporary, Rock, Urban, and Urban Adult Contemporary. R\&R also maintains a list of stations in 8 formats, each of which is one or two of the underlying R\&R12. ${ }^{19}$ We term this shorter list of formats the "R\&R8." By linking these lists of station lists with our data, we can calculate the fraction of stations in each R\&R8 format falling into each Duncan format. Table 3 reports these distributions. With the exception of the Adult Contemporary/Hot Adult Contemporary joint format, two thirds or more of stations in the R\&R formats map into one Duncan format. For example, 71 percent of R\&R's "Adult Alternative" stations are classified as AOR/P by Duncan, 74 percent of R\&R 's "Alternative" stations are AOR/NR in Duncan. The correspondences

\footnotetext{
${ }^{16}$ In reality, stations also choose times of day, as well as overall frequency. This could be accomplished with separate $n$ vectors for different parts of the day.

${ }^{17}$ The playlist data are from Radioairplay: the Net's Alternative Trade (http://www.radioairplay.com/). ${ }^{18}$ According to Ron Rodrigues, Editor-In-Chief of Radio \& Records, the "airplay charts are derived from airplay reports of 1000 radio stations of varying formats from across the country and in different market sizes." Email communication with author, March 4, 1998. See http://www.rronline.com.
} 
are even closer for country, jazz, and rock. Almost 85 percent of R\&R's Rock/Active Rock stations are AOR in Duncan. Roughly 95 percent of R\&R's Country and Jazz/NAC stations are classified by Duncan as Classical and Jazz, respectively.

Knowing how the R\&R formats relate to the Duncan formats, it is interesting to examine the inter-format correspondence in top 30's. The question, addressed in table 4, is, "how many songs in one format's top 30 also appear in another format's top 30?" The number 30 appears along the main diagonal of this table by construction. The lower the correspondence, the more variety that additional formats add. Correspondingly, the greater the correspondence, the closer are the two formats in product space. Some formats, such as country and jazz, air songs that are not broadcast by other formats. Others exhibit a great deal of overlap. For example, 19 of the top 30 songs in the Top 40 format are also in the Hot Adult Contemporary top 30. Twenty of the top 30 rock songs are also in the Active Rock top 30. While neither classical, classic album oriented rock, nor oldies music formats appear in $R \& R$, we assume that their top 30s exhibit no overlap with other formats (or each other).

The maximum number of top 30 songs from one RR12 format played on stations in another RR12 format is 20 (Active Rock and Rock), and virtually all of the stations in both of the R\&R formats are classified by Duncan as AOR. R\&R's Alternative, generally classified by Duncan as AOR/NR, overlaps substantially with R\&R's Rock and Active Rock categories (Duncan's AOR) with 14 and 16 overlapping top 30 songs, respectively. Still, the closest formats in Duncan appear to offer some distinct programming (at least

\footnotetext{
${ }^{19}$ In the R\&R8 Adult Contemporary and Hot Adult Contemporary are grouped together as one format, as are Top 40 (Pop) with Top 40 (Rhythmic), Urban with Urban Adult Contemporary, and Rock with Active Rock.
} 
among their top 30 songs). Hence, while not all formats add the same amount of variety to an existing set of stations, the number of formats nevertheless appears to be monotonically related to available programming variety.

\section{Empirical Strategy}

Table 2 neatly illustrates the dimensions of exogenous variation that we will exploit to measure the impact of ownership concentration on variety. The ownership restrictions were relaxed to different extents in markets of different sizes, and this gives rise to different extents of increase in ownership concentration across markets of different sizes. We treat this as exogenous variation in the extent of increased concentration.

Thus, we can address possible endogeneity of ownership concentration in particular markets by instrumenting changes in ownership concentration with measures of market size (the variables determining which ownership limits apply in each market). Determining which ownership limits apply in each market is not as straightforward as one might hope, however. According to FCC staffer Alan Aronowitz, a market, for broadcast purposes, "is defined by the signal contours of the station(s) involved." To determine the number of stations in a subject station's market, one "basically counts the number of signals that overlap with the subject station to determine the number of signals in that station's market." ${ }^{20}$ Thus the FCC maintains no list of markets in each ownership restriction category.

\footnotetext{
${ }^{20}$ Electronic mail communication with Mr. Alan Aronowitz, February 24, 1997.
} 
An appropriate instrument for change in ownership concentration is, thus, a variable that determines the number of stations likely to be in stations' markets, and therefore the relevant ownership limit. We use terms in population for this purpose. As has been documented elsewhere (Berry and Waldfogel, 1996), measures of market size, such as population, determine the number of viable stations and are therefore suitable instruments for the ownership-limit-change regime. The relationship between market size and change in concentration in table 2 suggests the promise of this empirical strategy. We propose to identify the effect of the change in concentration on variety using the variation in concentration associated with market size. Table 5 shows that 1993-1997 changes in ownership concentration (measured in both number and equivalent terms) vary systematically with 1993 population, showing the promise of our instrumental variables strategy.

\section{Results}

\section{Concentration and Station Entry}

The first question we address is whether concentration affects the number of stations operating. ${ }^{21}$ We test this by regressing the measures of the change in number of stations in a market on changes in measures of the number of owners, as well as population. Table 6 reports results of these regressions. The first two columns are OLS regressions, using "numbers" and "equivalents," respectively. Both specifications show a positive and significant coefficient on the measures of owners. Within markets, after

\footnotetext{
${ }^{21}$ Note that, give multi-station firms, the number of stations is not the number of firms. Rather, it is the number of products. We use the term "station entry" to refer to the launch of additional stations, as opposed to firm entry into a market.
} 
accounting for the common time effect and the growth in stations associated with MSA population growth, markets with greater growth in concentration have less station growth.

As discussed, the number of owners is an endogenous variable. Furthermore, to the extent that the number of stations per owner is fixed, the relationship between stations and owners is an accounting identity. Both of these concerns create problems for OLS estimation approaches. A natural way to deal with these problems is to instrument for the change in owners using terms in population, as we described above (see table 5 for evidence on the first-stage regressions). The last two columns of table 6 report IV estimates. In both IV specifications, the number of owners exerts a positive and significant effect on entry, and magnitudes are similar to the OLS coefficients, again indicating that concentration reduces entry.

We are concerned that license scarcity (i.e. that station entry may be possible in small but not in large markets) may affect this result. To check this we also run the regressions in table 6 omitting the top 25 and top 50 markets. The results hold in three of the four specifications. In the IV "equivalent" specification, the owner coefficient becomes insignificant. Subject to this caveat, we conclude that the evidence generally supports the result that concentration reduces station entry.

That concentration dampens station entry is especially interesting given the possibility of excess station entry into radio broadcasting. Berry and Waldfogel (1996) estimate that, from the standpoint of maximizing the joint surplus of the buyers and sellers of advertising (that is, ignoring the value of programming to listeners), free entry of stations generated three times too many stations in the top 135 US markets in 1993. It is important to emphasize, however, that those estimates ignore the value of programming to 
listeners. Consequently, the reduction in the number of stations associated with increased concentration may have negative welfare consequences.

\section{Concentration and Variety}

The second question we address is how the increased concentration occurring under the 1996 Telecom Act affects programming variety. We know (from table 2) that both the average numbers of stations and formats available in each market rise substantially between 1993 and 1997. The question we address here is whether the growth in formats is larger in markets with greater growth in concentration (reduction in the number of owners).

We estimate equations two ways. First, regress change in variety measures on changes in the number of owners and population. The coefficient on change in owners in this regression shows the overall effect of the policy on programming variety. Second, we also report regressions which include the change in the number of stations as a regressor. The coefficient on change in owners in these regressions shows a relationship of theoretical interest, the effect of concentration on variety, conditional on the number of stations.

The first four columns of table 7 report the regressions omitting change in the number of stations. Columns 1 and 2 report OLS regressions in number and equivalent terms, respectively. Columns 3 and 4 report IV regressions, instrumenting change in owners with terms in 1993 population. Population is positively, although not always significantly, related to variety in both regressions. The most interesting question for our

purposes is, of course, the coefficient on owners. The evidence is mixed: concentration 
bears an insignificant relationships in the both the OLS and IV numbers specfications and a significant negative relationship in both of the number-equivalent specifications. The evidence based on the equivalent specifications indicates that increased concentration increases the available programming variety. Using the IV results, a one owner-equivalent reduction in the number of owners (and therefore an increase in concentration) raises by 0.199 (std. err. $=0.069)$ the number of formats available. Given that owner-equivalents decreased by 3.7 between 1993 and 1997, the changes in concentration made possible by the Telecom Act increased average available formats per market by about 0.7 . This is roughly a 10 percent increase in format equivalents. This result indicates that the 1996 Telecom Act increased available variety, as measured by format equivalents.

The last four columns of table 7 report regressions that adjust for the number of stations, allowing us to isolate the effect of concentration per se, as opposed to the effect of the Act. Each of the four coefficients is negative and significant, and the IV coefficients are larger in absolute value. This indicates that concentration promotes variety for a given number of products.

The results in this section indicate, at least for radio, that concentration increases available product variety. While increased concentration may decrease welfare via increased prices, it may improve listener welfare through increased variety. In addition to the usual attention paid to pricing, regulators might therefore also consider effects on product variety.

\section{Variety and Listening}


While we have documented that ownership concentration increases available programming variety, we are also interested in whether the greater variety associated with increased concentration leads to greater satisfaction for listeners. In principle we could assess the value of additional variety to listeners if they paid a price for listening. Because radio programming is free to listeners, we cannot measure its value to listeners. We can observe the number of persons listening but no price paid. In effect, we observe the point where listeners' programming demand curve hits the quantity axis but not its slope. Despite the inherent shortcomings of the data in this context, a natural question we can address is whether listening increases in available programming variety. Such a positive relationship would be sufficient to demonstrate the value of variety to listeners, although it is not necessary. ${ }^{22}$ Earlier studies show a positive cross-sectional relationship between available formats and listening share (Rogers and Woodbury, 1996). In Berry and Waldfogel (1998) we document this positive relationship across markets, instrumenting stations and formats with population.

Here, using longitudinal data, we ask whether listening changes with changes in variety. Our listening measure is the Arbitron average quarter hour (AQH) listening share, the percent of the population listening to radio for at least five minutes during an average 15 minute period, between $6 \mathrm{AM}$ and midnight. Table 8 reports results of regressions of the change in $\mathrm{AQH}$ listening shares on changes in the numbers (and number equivalents) of formats, stations, and owners. Apart from the constant term, little is significant in the OLS regressions in table 8 . Constant terms are systematically negative in the listening

\footnotetext{
${ }^{22}$ Additional variety may be valuable to listeners even if total listening were invariant with respect to available programming variety. With greater variety, listeners will shift to weakly preferred alternatives. Even if no new listeners are drawn from non-listening, existing listeners may be more satisfied.
} 
regressions, reflecting declining listening over this period. Columns 3 and 4 exclude $\Delta$ stations and $\Delta$ owners to see whether a possible relationship between variety and listening is obscured by collinearity among the regressors. Even alone, however, $\Delta$ formats has no effect on $\Delta$ listening in the OLS specification. We are, of course, concerned that $\Delta$ formats is endogenous, so we also employ an IV strategy, instrumenting for $\Delta$ formats with terms in 1993 population. Columns 5 and 6 show that format growth varies systematically with market size. The last two columns of table 8 repeat the specification from columns 3 and 4, now instrumenting $\Delta$ formats. Instrumented $\Delta$ formats bears a positive, but only marginally significant relationship to $\Delta$ listening. These results provide only weak evidence that increased variety occurring under the Telecom Act has mitigated the trend of declining listening. While the estimated longitudinal relationship between listening and formats is not as strong as the cross sectional relationship estimated elsewhere, the longitudinal test may suffer from measurement error in $\Delta$ formats.

\section{What Explains the Results?}

How can we rationalize the joint results above that concentration increases variety and decreases station entry? To answer this question it is useful to think about firm strategies made available by the relaxation in ownership constraints. What strategies can multi-station firms pursue that are unavailable to single-station firms? First, owners of multiple stations may enjoy economies of scale, either associated with the number of stations owned nationally or the number of stations owned locally (see Myerson, 1998). Under free entry, reduced costs of station operations would lead, by itself, to more station entry. With lower station costs, a market can support more stations. This is, of course, 
not what we find. Hence, the results cannot be explained solely by economies of scale that lead to general cost reduction.

While the results above are not apparently explained by the economies associated with the number of stations that firms operate, the results may be explained by the firms' choices of formats for their multiple stations. In particular, firms may, by their choices of local station formats, preempt competitor entry. Spatial preemption implies that stations would choose to locate in closely related formats to avoid creating holes in the product space for new entrants. Spatial preemption, balanced against the desire to avoid stealing business from oneself, could explain why concentration is associated with fewer stations but more variety. Spatial preemption also implies that jointly owned local stations would locate in similar (but not identical) formats. The merged entities might offer more varieties, as Schmalensee (1978) has argued.

The following example illustrates this argument. Suppose a firm owning a top 40 station purchases another firm operating another top 40 station in the market. The merged firm clearly does not want to operate two top 40 stations that steal each other's business. On the other hand, if there is free entry, the firm also cannot move one of the stations to a distant programming format. A possible strategy that balances these concerns is to operate both of the stations in adjacent formats, attracting some new listeners without opening a profitable niche for a competitor. We can test for the use of this strategy by asking whether jointly owned local stations are more likely than unrelated stations to operate in adjacent, or overlapping, formats.

However, jointly owned local stations might be more likely than unrelated stations to program in similar formats for reasons other than spatial preemption. There may be 
production complementarities arising from offering similar programming on a firm's different stations. For example, a firm's expertise at programming might be formatspecific. Knowledge of, say, top 40 programming might lower the cost of launching a top 40/adult contemporary station. This sort of economy could explain programming overlap among both national and local sibling stations. Further, economies in the sale of advertising could encourage programming in adjacent formats. A firm's experience selling ads to businesses patronized by, say, top 40 listeners may lower the cost of entry into formats that would sell ads to similar businesses. To the extent that advertising is sold locally, this would lead to overlap among local, but not necessarily among national jointly owned stations.

Because stations compete for listeners only locally, considerations of strategic product location arise only locally. Issues of scale economies associated with station adjacency arise both nationally and locally. This logic suggests that the tendency for firms to operate adjacent stations across markets reflects production cost economies. An additional tendency for a firm's locally owned stations to operate in adjacent formats, by contrast, could reflect strategic considerations.

Table 9 presents the probability that pairs of stations broadcast programming in similar formats according to whether the two stations are jointly owned and, if jointly owned, whether the two stations broadcast from the same, or different markets. We measure similarity of programming using the format overlap information reported in table $4 .^{23}$ Working with the population of possible station pairs across markets is complicated

\footnotetext{
${ }^{23}$ To determine whether two stations have overlapping programming, we must map all of Duncan's formats into Radio and Records formats. For some formats that do not appear in Radio and Records, we have grouped them together and have assumed that their programming does not overlap other formats'
} 
somewhat by the large number of station pairs one needs to create. There are over 5,000 stations in the 1997 data. Hence, there are over 12.5 million national station pairs. ${ }^{24}$ Rather than work with the entire unwieldy sample, we work with a ten percent sample of underlying stations, which generates 180,234 pairs of stations. Of these, 1,508 pairs are jointly owned. Of these, only 57 are local siblings. The last sample is too small to generate meaningful comparisons. However, we can create the full population of local station pairs, and it contains 4,433 pairs. $^{25}$

The probability that two randomly selected stations from across the markets broadcast formats that are similar (any overlap among top 30 songs) but not the same (not the same Duncan format) is 17.62 percent. The probability that random pairs broadcast in the same format is 5.87 percent. Unrelated station pairs make up the overwhelming majority of pairs, so their probabilities are nearly identical.

We can test for production economies associated with format adjacency by comparing the probabilities of similarity and "sameness" of unrelated pairs against national but non-local siblings, shown in rows 2 and 3 of table 9, respectively. National but nonlocal siblings are substantially (and significantly) more likely than unrelated pairs to broadcast in similar and identical formats. This provides evidence of production

programming (these include Big Band/Nostalgia, Classical, Full Service/Variety, Kids, News, Oldies, Talk, Religious, and Spanish). We list the mapping below (Duncan's formats appear parenthetically following each Radio and Records format: Adult Alternative (AC/AOR, AC/NR, AOR/AC, AOR/P), Adult Contemporary (AC, AC/CHR, AC/SAC, EZ, EZ/SAC, SAC), Alternative (AOR/NR, CHR/NR), Big Band/Nostalgia (BB, BB/EZ, BB/REL, BB/T), Country (C, C/FS), Classical (CL), Full Service/Variety (FS, FS/T), Jazz (J), Kids (KIDS), News (N, N/T), Oldies (OLD, CL HITS), Religious (REL, G), Rock (AOR, CL AOR, AOR/CL), Spanish (SP), Top 40 (CHR, CHR/AC), Top 40/Urban (CHR/B, CHR/U), Urban Adult Contemporary (B/AC), Urban (B, B/G, B/O, B/T, E).

${ }^{24}$ With $N$ stations, there are $N(N-1) / 2$ station pairs.

${ }^{25}$ This sample is workable because it only involves the cross product of each market's stations, which generates a total of roughly 75,000 pairs. 
complementarities. Because stations do not compete for listeners across markets, this across-market format adjacency does not necessarily reflect any attempt at spatial preemption.

We can test for spatial preemption by comparing the probabilities of formats similarity and "sameness" of national but non-local siblings against local siblings, shown in rows 3 and 4 of table 9, respectively. Local siblings are substantially - and significantly more likely than national but non-local siblings to broadcast in similar formats. They are also substantially - and significantly - less likely to broadcast in the same format. These results are consistent with intentional, strategic spatial preemption. Of course, they could arise because of local economies of scale associated with format adjacency (as would occur, for example, if a local advertising sales staff had a cost advantage selling to local businesses patronized by listeners to formats similar to the firm's existing local formats). Regardless of whether the elevated format similarity among local, as opposed to non-local siblings arises because of strategic, or intentionally preemptive, behavior, it can still be preemptive in effect. While it would be interesting to know why firms locate their stations where they do, our argument that product positioning is preemptive does not require firms to have strategic intentions.

We can construct another test that may distinguish spatial preemption from other explanations of heightened format adjacency among local siblings. Spatial preemption has implications for the relationship between the degree of overlap among jointly owned local stations and the size of the market. If firms cluster to preempt entry, then the density of listeners to a format in a market, which is presumably proportional to population, will determine how closely firms must cluster stations to preempt entry. For example, in a 
populous market, to preempt entry at top 40, a firm operating a top 40 station must also operate something very similar to top 40 . In a smaller market, the firm could protect its position at top 40 with a local sibling station in a more distant format. If this argument is correct, then the average amount of programming overlap among local siblings will increase in market size. Table 10 presents regressions of the average amount of overlap among local siblings on measures of market size, and the coefficients on population (or its $\log$ ) are uniformly positive and significant. To check whether our result is an artifact of "product congestion" that increases in market size regardless of whether pairs are jointly owned, we include some specifications with the average level of overlap among nonsiblings in the market. The positive relationship between local sibling overlap and market size survives intact. This result is consistent with spatial preemption and is difficult to explain using scale economies.

\section{Conclusion}

It is well known in theory that free entry into differentiated product markets can generate sub-optimal configurations of firms and products. Given this possibility, is it important to know what sorts of policies can affect entry and product variety. Between 1993 and 1997 ownership concentration and the programming variety available in local radio markets both increased substantially. Using instruments justified by the change in local ownership rules under the 1996 Telecommunications Act, we have presented evidence that increased concentration caused an increase in available programming variety. The increased concentration also appears to have reduced the amount of station entry. We argue that the effects that we document can be explained as a result of firms locating 
jointly owned stations in ways that preempt entry. Pairs of jointly owned local stations are substantially more likely than jointly owned non-local station pairs to program in nearby formats. Furthermore, the proximity of joint owners' stations is greater in larger markets. Because a full welfare analysis requires information on the effects on advertising prices, as well as the effects on entry and variety, we cannot say whether, overall, the Act has been "good" or "bad." Presumably, the increased concentration has allowed firms to exercise some monopoly power over prices (see Klein, 1997). At the same time, our results at least suggest that the increased concentration has been good for listeners. Antitrust authorities considering radio mergers might want to take such effects into account when they try to anticipate the effect of mergers on prices. 


\section{References}

Alexander, Peter J. "Product Variety and Market Structure." Journal of Economic Behavior \& Organization 32, (1997):207-214.

Anderson, Simon P., Andre de Palma, Jacques-Francois Thisse. Discrete Choice Theory of Product Differentiation. Cambridge and London: MIT Press. 1992.

Anderson, Simon P., Andre DePalma, Yurii Nesterov. "Oligopolistic Competition and the Optimal Provision of Products." Econometrica 63, 6 (1995):1281-1302.

The Arbitron Company, Radio Metro Market Guide, 1993-1994. New York: The Arbitron Company, 1994.

The Arbitron Company, Radio USA, Spring 1993,97. New York: The Arbitron Company, 1993,97.

Berry Steven T. and Joel Waldfogel. "Free Entry and Social Inefficiency in Radio Broadcasting." NBER working paper 5528, April 1996.

Berry Steven T. and Joel Waldfogel. "Public Radio in the United States: Does it Correct Market Failure or Cannibalize Commercial Stations?" Journal of Public Economics, forthcoming, 1998.

Bonnano, G. (1987) "Location Choice, Product Prolififeration and Entry Deterrence." Review of Economic Studies 54 (1): 37-45 (Jan 1987)

Dixit, Avinash and Joseph E. Stiglitz. "Monopolistic Competition and Optimum Product Diversity." American Economic Review 67, (1977): 297-308.

Klein, Joel I. "DOJ Analysis of Radio Mergers." Address Presented at ANA Hotel, Washington, D.C. February 19, 1997.

Judd, Kenneth L. "Credible Spatial Preemption." Rand Journal of Economics 16, 2 (1985):153-166.

Lancaster, Kelvin. Variety, Equity, and Efficiency. Coumbia University Press: New York, 1979.

Mankiw, N. Gregory and Michael D. Whinston. "Free Entry and Social Inefficiency." Rand Journal of Economics 17, no. 1 (Spring 1986):48-58. 
Mazzeo, Michael. "Product Choice and Oligopoly Market Structure," Kellog School of Management Working Paper, 1998.

Myerson, Allen R. "Riding Radio Merger Wave, Chancellor Will Buy Capstar." New York Times. August 28, 1998, p. D4.

Ness, Susan. "Remarks of Commissioner Susan Ness before the Michigan Association of Broadcasters." Washington, DC: FCC. February 25, 1997

Rogers, R. P. and J. R. Woodbury "Market Structure, Program Diversity, and Radio Audience Size." Contemporary Economic Policy 14, no.1 (1996):81-91.

Schmalensee, Richard. "Entry Deterrence in the Ready-to-Eat Breakfast Cereal Industry." Bell Journal of Economics 9, 2 (1978): 305-327.

Spence, Michael. "Product Selection, Fixed Costs, and Monpolistic Competition." Review of Economic Studies 43, (1976): 217-236.

Steiner, Peter O. "Program Patterns and the Workability of Competition in Radio Broadcasting." Quarterly Journal of Economics 66, no. 2 (May 1952):194-223.

Sutton, John. Sunk Costs and Market Structure. Cambridge, MA: MIT Press. 1991. 


\section{Table 1}

Distribution of Stations by Format, 1993-1997

\begin{tabular}{|c|c|c|}
\hline Format & 1993 & 1997 \\
\hline$\overline{\text { Adult Contemporary }}$ & $8.51 \%$ & $6.61 \%$ \\
\hline Adult Contemporary/Album Oriented Rock & $0.12 \%$ & $0.07 \%$ \\
\hline Adult Contemporary/Contemp. Hit Radio & $0.18 \%$ & $2.01 \%$ \\
\hline Adult Contemporary/Full Service & $0.02 \%$ & $0.00 \%$ \\
\hline Adult Contemporary/New Rock & $0.00 \%$ & $0.65 \%$ \\
\hline Adult Contemporary/Oldies & $0.10 \%$ & $0.00 \%$ \\
\hline Adult Contemp./Soft Adult Contemp. & $0.00 \%$ & $0.14 \%$ \\
\hline Album Oriented Rock & $10.31 \%$ & $5.95 \%$ \\
\hline Album Oriented Rock/Adult Contemp. & $0.10 \%$ & $0.05 \%$ \\
\hline Album Oriented Rock/New Rock & $0.00 \%$ & $3.29 \%$ \\
\hline Album Oriented Rock/Progressive & $0.00 \%$ & $1.33 \%$ \\
\hline Black & $5.28 \%$ & $3.87 \%$ \\
\hline Black/Adult Contemp. & $0.25 \%$ & $1.69 \%$ \\
\hline Black/Gospel & $0.08 \%$ & $0.48 \%$ \\
\hline Black/Oldies & $0.06 \%$ & $0.43 \%$ \\
\hline Black/Talk & $0.08 \%$ & $0.10 \%$ \\
\hline Big Band/Nostalgia & $3.97 \%$ & $5.08 \%$ \\
\hline Big Band/Nostalgia/Easy Listening & $0.10 \%$ & $0.05 \%$ \\
\hline Big Band/Nostalgia/Full Service & $0.10 \%$ & $0.00 \%$ \\
\hline Big Band/Nostalgia/Oldies & $0.02 \%$ & $0.00 \%$ \\
\hline Big Band/Nostalgia/Religious & $0.00 \%$ & $0.02 \%$ \\
\hline Big Bang/Nostalgia/Talk & $0.00 \%$ & $0.02 \%$ \\
\hline Country & $14.13 \%$ & $14.06 \%$ \\
\hline Country/Full Service & $0.33 \%$ & $0.20 \%$ \\
\hline Contemporary Hit Radio & $8.77 \%$ & $6.42 \%$ \\
\hline Contemporary Hit Radio/Adult Contemp. & $0.23 \%$ & $0.75 \%$ \\
\hline Contemporary Hit Radio/New Rock & $0.00 \%$ & $0.15 \%$ \\
\hline Contemporary Hit Radio/Spanish & $0.06 \%$ & $0.00 \%$ \\
\hline Contemporary Hit Radio/Urban & $0.18 \%$ & $0.89 \%$ \\
\hline Classical & $1.25 \%$ & $1.16 \%$ \\
\hline Classic Album Oriented Rock & $2.80 \%$ & $4.38 \%$ \\
\hline Classic Hits & $0.00 \%$ & $1.33 \%$ \\
\hline Ethnic & $0.31 \%$ & $0.24 \%$ \\
\hline Easy Listening & $0.02 \%$ & $0.15 \%$ \\
\hline Easy Listening/Soft Adult Contemp. & $0.06 \%$ & $0.02 \%$ \\
\hline Full Service/Variety & $3.66 \%$ & $1.57 \%$ \\
\hline Full Service/Variety/Talk & $0.74 \%$ & $1.31 \%$ \\
\hline Gospel & $1.08 \%$ & $1.04 \%$ \\
\hline Gospel/Black & $0.02 \%$ & $0.00 \%$ \\
\hline Jazz & $1.10 \%$ & $1.87 \%$ \\
\hline Kids & $0.00 \%$ & $0.02 \%$ \\
\hline
\end{tabular}


News

$0.63 \% \quad 1.19 \%$

News/Talk

$2.97 \% \quad 2.64 \%$

New Adult Contemp./Album Oriented Rock

$0.04 \% \quad 0.00 \%$

Oldies

$6.36 \% \quad 6.22 \%$

Religious

$3.82 \% \quad 4.50 \%$

Soft Adult Contemp.

$6.85 \% \quad 4.04 \%$

Spanish

$3.25 \% \quad 4.41 \%$

Sports

$1.29 \% \quad 2.83 \%$

Talk

$4.52 \% \quad 6.51 \%$

Talk/Classic Album Oriented Rock

$0.00 \% \quad 0.12 \%$

Talk/Jazz

$0.00 \% \quad 0.07 \%$

Talk/Oldies

$0.08 \% \quad 0.00 \%$

Unknown

$6.20 \% \quad 0.10 \%$

Number of Stations

$5111 \quad 5869$

Effective Number of Formats

$14.14 \quad 17.70$ 


\section{Table 2}

Average Stations, Ownership, and Formats in Each Market, 1993-1997

\section{Markets}

\begin{tabular}{lcccc}
\hline & 1993 & 1997 & $\begin{array}{c}\% \\
\text { change, } \\
\text { '93-'97 }\end{array}$ \\
\hline \hline Numbers & Stations & 21.3 & 24.5 & 15.0
\end{tabular}

Owners

Formats

Ownership

HHI

Number Stations

Equivalents

Owners

Formats

HHI by

1997

Population

Quartile

(Avg. Pop., 000s)

(113.9)
Quartile 2

(230.6)

Quartile 3

(437.1)

Quartile 4

$(2,084.5)$ $\begin{array}{lll}18.6 & 14.9 & -19.9\end{array}$

$\begin{array}{lll}11.5 & 14.8 & 28.7\end{array}$

$\begin{array}{lll}1272 & 2096 & 64.8\end{array}$

$\begin{array}{lll}11.5 & 13.7 & 19.1\end{array}$

$\begin{array}{lll}9.2 & 5.5 & -40.2\end{array}$

$\begin{array}{ccc}6.9 & 8.9 & 30.0 \\ 1775 & 2512 & 41.5\end{array}$

$\begin{array}{ccc}6.9 & 8.9 & 30.0 \\ 1775 & 2512 & 41.5\end{array}$


Table 3 Mapping between Radio and Records and Duncan Formats

\begin{tabular}{|c|c|c|}
\hline R \& R Format & Duncan Format & Percent \\
\hline \multirow[t]{5}{*}{$\begin{array}{l}\text { Adult Alternative } \\
\text {. }\end{array}$} & $\overline{\mathrm{AOOR} / \mathrm{P}}$ & $71.0 \%$ \\
\hline & AOR/NR & $12.9 \%$ \\
\hline & $\mathrm{AC} / \mathrm{NR}$ & $6.5 \%$ \\
\hline & AOR & $6.5 \%$ \\
\hline & $\mathrm{AC} / \mathrm{AOR}$ & $3.2 \%$ \\
\hline \multirow[t]{15}{*}{ Adult Contemp./Hot Adult Contemp. } & $\mathrm{AC}$ & $53.3 \%$ \\
\hline & $\mathrm{SAC}$ & $18.1 \%$ \\
\hline & $\mathrm{AC} / \mathrm{CHR}$ & $14.8 \%$ \\
\hline & $\mathrm{AC} / \mathrm{NR}$ & $2.9 \%$ \\
\hline & CHR & $2.9 \%$ \\
\hline & $\mathrm{CHR} / \mathrm{AC}$ & $1.9 \%$ \\
\hline & AC/SAC & $1.0 \%$ \\
\hline & $\mathrm{AOR} / \mathrm{P}$ & $1.0 \%$ \\
\hline & $\mathrm{CHR} / \mathrm{NR}$ & $1.0 \%$ \\
\hline & $\mathrm{O}$ & $1.0 \%$ \\
\hline & AC/AOR & $0.5 \%$ \\
\hline & B & $0.5 \%$ \\
\hline & CL AOR & $0.5 \%$ \\
\hline & CL HITS & $0.5 \%$ \\
\hline & SP & $0.5 \%$ \\
\hline \multirow[t]{7}{*}{ Alternative } & AOR/NR & $74.0 \%$ \\
\hline & AOR & $12.0 \%$ \\
\hline & $\mathrm{AOR} / \mathrm{P}$ & $6.0 \%$ \\
\hline & $\mathrm{CHR} / \mathrm{NR}$ & $5.0 \%$ \\
\hline & $\mathrm{AC} / \mathrm{NR}$ & $1.0 \%$ \\
\hline & CHR & $1.0 \%$ \\
\hline & SP & $1.0 \%$ \\
\hline \multirow{7}{*}{ Top 40 (Pop \& Urban) } & $\mathrm{CHR}$ & $82.3 \%$ \\
\hline & $\mathrm{CHR} / \mathrm{U}$ & $8.2 \%$ \\
\hline & $\mathrm{CHR} / \mathrm{AC}$ & $4.8 \%$ \\
\hline & AOR & $2.0 \%$ \\
\hline & $\mathrm{B}$ & $1.4 \%$ \\
\hline & $\mathrm{AC}$ & $0.7 \%$ \\
\hline & SP & $0.7 \%$ \\
\hline \multirow[t]{6}{*}{ Country } & $\mathrm{C}$ & $96.1 \%$ \\
\hline & $\mathrm{C} / \mathrm{FS}$ & $1.7 \%$ \\
\hline & BB & $0.6 \%$ \\
\hline & $\mathrm{CHR}$ & $0.6 \%$ \\
\hline & SAC & $0.6 \%$ \\
\hline & $\mathrm{T}$ & $0.6 \%$ \\
\hline \multirow[t]{2}{*}{ Jazz/New Adult Contemp. } & $\mathrm{J}$ & $94.7 \%$ \\
\hline & $\mathrm{B} / \mathrm{AC}$ & $5.3 \%$ \\
\hline \multirow[t]{4}{*}{ Rock } & AOR & $84.9 \%$ \\
\hline & CL AOR & $7.5 \%$ \\
\hline & AOR/NR & $6.9 \%$ \\
\hline & CL HITS & $0.6 \%$ \\
\hline \multirow[t]{4}{*}{ Urban and Urban Adult Contemp. } & $\mathrm{B}$ & $78.0 \%$ \\
\hline & $\mathrm{B} / \mathrm{AC}$ & $14.6 \%$ \\
\hline & $\mathrm{BB}$ & $4.9 \%$ \\
\hline & $\mathrm{B} / \mathrm{O}$ & $2.4 \%$ \\
\hline
\end{tabular}


Table 4

Number of Each Format's Top 30 Songs in other Formats' Top 30

\begin{tabular}{|c|c|c|c|c|c|c|c|c|c|c|c|c|}
\hline & $\mathrm{AA}$ & $\mathrm{AC}$ & $\mathrm{AR}$ & ALT & $\mathrm{T} 40$ & $\mathrm{~T} 40 / \mathrm{U}$ & $\mathrm{C}$ & $\mathrm{HAC}$ & $\mathbf{J}$ & Rock & UAC & URB \\
\hline Adult Alternative (AA) & 30 & 4 & 6 & 11 & 10 & 0 & 0 & 15 & 0 & 9 & 0 & 0 \\
\hline Adult Contemp. (AC) & 4 & 30 & 0 & 1 & 8 & 4 & 1 & 10 & 0 & 1 & 0 & 0 \\
\hline Active Rock (AR) & 6 & 0 & 30 & 16 & 3 & 0 & 0 & 4 & 0 & 20 & 0 & 0 \\
\hline Alternative (ALT) & 11 & 1 & 16 & 30 & 7 & 0 & 0 & 8 & 0 & 14 & 0 & 0 \\
\hline Top 40 (T40) & 10 & 8 & 3 & 7 & 30 & 11 & 0 & 19 & 0 & 4 & 4 & 2 \\
\hline Top 40/Urban (T40/U) & 0 & 4 & 0 & 0 & 11 & 30 & 0 & 3 & 0 & 0 & 10 & 15 \\
\hline Country ( C ) & 0 & 1 & 0 & 0 & 0 & 0 & 30 & 0 & 0 & 0 & 0 & 0 \\
\hline $\begin{array}{l}\text { Hot Adult Contemp. } \\
\text { (HAC) }\end{array}$ & 15 & 10 & 4 & 8 & 19 & 3 & 0 & 30 & 0 & 5 & 0 & 0 \\
\hline $\begin{array}{l}\text { Jazz/New Adult } \\
\text { Contemp. (J) }\end{array}$ & 0 & 0 & 0 & 0 & 0 & 0 & 0 & 0 & 30 & 0 & 0 & 0 \\
\hline Rock & 9 & 1 & 20 & 14 & 4 & 0 & 0 & 5 & 0 & 30 & 0 & 0 \\
\hline $\begin{array}{l}\text { Urban Adult Contemp. } \\
\text { (UAC) }\end{array}$ & 0 & 0 & 0 & 0 & 4 & 10 & 0 & 0 & 0 & 0 & 30 & 13 \\
\hline Urban (URB) & 0 & 0 & 0 & 0 & 2 & 15 & 0 & 0 & 0 & 0 & 13 & 30 \\
\hline
\end{tabular}

Source: Radio and Records Online, National Airplay Charts for the week of Feb. 27, 1998. 
Table 5

Changes in Concentration Measure and Population Level

\begin{tabular}{lcc}
\hline & \multicolumn{2}{c}{ Dependent Variable: $\Delta$ Owners, $1993-1997$} \\
Variable & Numbers & Equivalents \\
\hline \hline Constant & -1.976 & -2.459 \\
& $(0.313)$ & $(0.205)$ \\
1993 Population & -3.10 & -2.105 \\
(millions) & & \\
& $(0.396)$ & $(0.259)$ \\
1993 Population & 0.180 & 0.112 \\
Squared & & \\
& $(0.037)$ & $(0.024)$ \\
R-sq. & 0.2575 & 0.2936 \\
N & 243 & 243
\end{tabular}

Note: Standard errors in parentheses. 
Table 6: Station Entry and Ownership Concentration

\begin{tabular}{|c|c|c|c|c|}
\hline \multirow{3}{*}{$\begin{array}{l}\text { Dependent } \\
\text { variable } \\
\text { Estimation Tech. }\end{array}$} & \multicolumn{4}{|c|}{$\Delta$ Stations, 93-97 } \\
\hline & \multicolumn{2}{|c|}{ OLS } & \multicolumn{2}{|c|}{ IV } \\
\hline & Number & Equiv. & Number & Equiv. \\
\hline Constant & $\begin{array}{c}5.126 \\
(0.239)\end{array}$ & $\begin{array}{c}2.871 \\
(0.186)\end{array}$ & $\begin{array}{c}5.279 \\
(0.332)\end{array}$ & $\begin{array}{c}3.088 \\
(0.297)\end{array}$ \\
\hline$\Delta$ Owners & $\begin{array}{c}0.525 \\
(0.035)\end{array}$ & $\begin{array}{c}0.216 \\
(0.041)\end{array}$ & $\begin{array}{c}0.572 \\
(0.081)\end{array}$ & $\begin{array}{c}0.283 \\
(0.082)\end{array}$ \\
\hline$\Delta$ Pop. (m) & $\begin{array}{l}0.230 \\
(4.33)\end{array}$ & $\begin{array}{c}3.486 \\
(2.914)\end{array}$ & $\begin{array}{c}1.106 \\
(4.541)\end{array}$ & $\begin{array}{c}4.695 \\
(3.199)\end{array}$ \\
\hline R-sq. & 0.4181 & 0.1051 & 0.4181 & 0.0950 \\
\hline $\mathrm{N}$ & 243 & 243 & 243 & 243 \\
\hline
\end{tabular}


Table 7: Programming Variety and Ownership Concentration

\begin{tabular}{|c|c|c|c|c|c|c|c|c|}
\hline & \multicolumn{8}{|c|}{$\Delta$ Formats } \\
\hline & \multicolumn{2}{|c|}{ OLS } & \multicolumn{2}{|c|}{ IV } & \multicolumn{2}{|c|}{ OLS } & \multicolumn{2}{|c|}{ IV } \\
\hline & $\begin{array}{c}\text { Numbers } \\
\text { (1) } \\
\end{array}$ & $\begin{array}{r}\text { Equiv. } \\
(2) \\
\end{array}$ & $\begin{array}{c}\text { Numbers } \\
\text { (3) } \\
\end{array}$ & $\begin{array}{r}\text { Equiv. } \\
(4) \\
\end{array}$ & $\begin{array}{c}\text { Numbers } \\
\text { (5) } \\
\end{array}$ & $\begin{array}{r}\text { Equiv. } \\
(6) \\
\end{array}$ & $\begin{array}{c}\text { Numbers } \\
\text { (7) } \\
\end{array}$ & $\begin{array}{r}\text { Equiv. } \\
(8) \\
\end{array}$ \\
\hline Constant & $\begin{array}{c}3.285 \\
(0.184)\end{array}$ & $\begin{array}{c}1.554 \\
(0.152)\end{array}$ & $\begin{array}{c}2.956 \\
(0.260)\end{array}$ & $\begin{array}{c}1.137 \\
(0.249)\end{array}$ & $\begin{array}{c}1.605 \\
(0.285)\end{array}$ & $\begin{array}{c}0.594 \\
(0.196)\end{array}$ & $\begin{array}{c}0.337 \\
(0.637)\end{array}$ & $\begin{array}{c}-0.178 \\
(0.349)\end{array}$ \\
\hline$\Delta$ Stations & & & & & $\begin{array}{c}0.328 \\
(0.045)\end{array}$ & $\begin{array}{c}0.334 \\
(0.048)\end{array}$ & $\begin{array}{c}0.495 \\
(0.088)\end{array}$ & $\begin{array}{c}0.422 \\
(0.060)\end{array}$ \\
\hline$\Delta$ Owners & $\begin{array}{c}0.018 \\
(0.031)\end{array}$ & $\begin{array}{l}-0.070 \\
(0.033)\end{array}$ & $\begin{array}{c}-0.083 \\
(0.064)\end{array}$ & $\begin{array}{c}-0.199 \\
(0.069)\end{array}$ & $\begin{array}{r}-0.154 \\
(0.037)\end{array}$ & $\begin{array}{c}-0.142 \\
(0.032)\end{array}$ & $\begin{array}{l}-0.367 \\
(0.102)\end{array}$ & $\begin{array}{r}-0.322 \\
(0.074)\end{array}$ \\
\hline$\Delta$ Pop. (m) & $\begin{array}{c}6.518 \\
(3.336)\end{array}$ & $\begin{array}{c}7.124 \\
(2.385)\end{array}$ & $\begin{array}{c}4.646 \\
(3.559)\end{array}$ & $\begin{array}{c}4.798 \\
(2.683)\end{array}$ & $\begin{array}{c}6.442 \\
(3.025)\end{array}$ & $\begin{array}{c}5.958 \\
(2.187)\end{array}$ & $\begin{array}{c}4.057 \\
(3.397)\end{array}$ & $\begin{array}{c}2.754 \\
(2.600)\end{array}$ \\
\hline R-sq. & 0.016 & 0.069 & 0.0718 & 0.0858 & 0.1944 & 0.2242 & 0.1852 & 0.2309 \\
\hline $\mathrm{N}$ & 243 & 243 & 243 & 243 & 243 & 243 & 243 & 243 \\
\hline
\end{tabular}


Table 8: Listening and Programming Variety

\begin{tabular}{|c|c|c|c|c|c|c|c|c|}
\hline \multirow[t]{2}{*}{$\begin{array}{l}\text { Dependent variable } \\
\text { Estimation Tech. }\end{array}$} & \multicolumn{4}{|c|}{$\begin{array}{c}\Delta \mathrm{AQH} \text { Listening } \\
\text { OLS }\end{array}$} & \multicolumn{2}{|c|}{$\begin{array}{c}\Delta \text { Formats } \\
\text { OLS }\end{array}$} & \multicolumn{2}{|c|}{$\begin{array}{l}\Delta \mathrm{AQH} \text { Listening } \\
\text { IV }\end{array}$} \\
\hline & Number & Equiv. & Number & Equiv. & Number & Equiv. & Number & Equiv. \\
\hline Constant & $\begin{array}{l}-1.098 \\
(0.159)\end{array}$ & $\begin{array}{l}-1.227 \\
(0.148)\end{array}$ & $\begin{array}{c}-0.969 \\
(0.121)\end{array}$ & $\begin{array}{l}-1.031 \\
(0.105)\end{array}$ & $\begin{array}{c}3.101 \\
(0.172)\end{array}$ & $\begin{array}{c}1.554 \\
(0.119)\end{array}$ & $\begin{array}{l}-1.949 \\
(0.783)\end{array}$ & $\begin{array}{l}-1.356 \\
(0.262)\end{array}$ \\
\hline$\Delta$ Formats & $\begin{array}{c}-0.034 \\
(0.034)\end{array}$ & $\begin{array}{r}-0.020 \\
(0.047)\end{array}$ & $\begin{array}{c}-0.014 \\
(0.031)\end{array}$ & $\begin{array}{c}0.008 \\
(0.043)\end{array}$ & & & $\begin{array}{c}0.277 \\
(0.232)\end{array}$ & $\begin{array}{c}0.173 \\
(0.129)\end{array}$ \\
\hline$\Delta$ Stations & $\begin{array}{c}0.037 \\
(0.026)\end{array}$ & $\begin{array}{c}0.020 \\
(0.039)\end{array}$ & & & & & & \\
\hline$\Delta$ Owners & $\begin{array}{l}-0.021 \\
(0.020)\end{array}$ & $\begin{array}{l}-0.057 \\
(0.024)\end{array}$ & & & & & & \\
\hline 1993 Pop. & & & & & $\begin{array}{c}0.531 \\
(0.218)\end{array}$ & $\begin{array}{c}0.842 \\
(0.150)\end{array}$ & & \\
\hline 1993 Pop. Sq. & & & & & $\begin{array}{l}-0.043 \\
(0.020)\end{array}$ & $\begin{array}{l}-0.070 \\
(0.014)\end{array}$ & & \\
\hline R-sq. & 0.0092 & 0.0237 & 0.008 & 0.0002 & 0.0241 & 0.1160 & 0.0082 & 0.0080 \\
\hline $\mathrm{N}$ & 243 & 243 & 243 & 243 & 243 & 243 & 243 & 243 \\
\hline
\end{tabular}

Note: Standard errors in parentheses. IV estimates use 1993 population and its square as instruments for the number, or number-equivalent, of formats. AQH listening is the percent of population listening to radio during an average quarter hour. "Equivalents" are calculated as the reciprocal of the format HHI. See text for details. 
Table 9

Joint Station Location and Local and National Joint Ownership

\begin{tabular}{|c|c|c|c|c|c|}
\hline & $\begin{array}{l}\text { Number of } \\
\text { Station Pairs }\end{array}$ & $\begin{array}{l}\text { Percent in } \\
\text { Same Format }\end{array}$ & $\begin{array}{l}\text { Percent in } \\
\text { Extremely } \\
\text { Similar (but not } \\
\text { same) Format } \\
(>10) \\
\end{array}$ & $\begin{array}{l}\text { Percent in Very or } \\
\text { Extremely Similar } \\
\text { (but not same) } \\
\text { Format }(>5)\end{array}$ & $\begin{array}{l}\text { Percent in Similar } \\
\text { (but not same) } \\
\text { Format }(>0)\end{array}$ \\
\hline 1. All Pairs & $180,234^{\mathrm{a}}$ & 5.87 & 4.01 & 7.24 & 17.62 \\
\hline 2. Unrelated Pairs & $178,667^{\mathrm{a}}$ & 5.84 & 4.00 & 7.22 & 17.58 \\
\hline $\begin{array}{l}\text { 3. Stations Owned by } \\
\text { Same Firm, } \\
\text { Broadcasting if } \\
\text { Different Market }\end{array}$ & $1,508^{\mathrm{a}}$ & 8.42 & 4.77 & 9.62 & 22.02 \\
\hline $\begin{array}{l}\text { Difference between } 2 \\
\text { and } 3\end{array}$ & & $\begin{array}{l}2.58 * \\
(0.61)\end{array}$ & $\begin{array}{r}0.77 \\
(0.51)\end{array}$ & $\begin{array}{l}2.40 * \\
(0.67)\end{array}$ & $\begin{array}{l}4.44^{*} \\
(0.98)\end{array}$ \\
\hline $\begin{array}{l}\text { 4. Stations Owned by } \\
\text { Same Firm and } \\
\text { Broadcasting from } \\
\text { the Same Market }\end{array}$ & $4,433^{\mathrm{b}}$ & 4.99 & 7.60 & 12.79 & 27.68 \\
\hline $\begin{array}{l}\text { Difference between } 3 \\
\text { and } 4\end{array}$ & & $\begin{array}{r}-3.44 * \\
(0.79)\end{array}$ & $\begin{array}{l}2.83 * \\
(0.68)\end{array}$ & $\begin{array}{l}3.17 * \\
(0.91)\end{array}$ & $\begin{array}{l}5.66^{*} \\
(1.26)\end{array}$ \\
\hline
\end{tabular}

Note: Calculations of quantities 1,2, and 3 from all possible station pairs created from a ten percent sample of stations in the database (these samples are denoted by superscript "a"). Calculation 4 based on the full population of same-city jointly owned station pairs (denoted by superscript "b"). Standard errors are in parentheses. 

Table 10

Average Overlap among Local Siblings and Market Size

\begin{tabular}{lllll}
\hline \multicolumn{5}{c}{ Dependent Variable: } \\
& Average Local Overlap among Siblings \\
\hline \hline Constant & 3.34 & 4.34 & -0.330 & 0.568 \\
& $(16.91)$ & $(6.90)$ & $(-0.34)$ & $(0.41)$ \\
1997 Population & 0.000390 & 0.00034 & & \\
& $(3.07)$ & $(2.611)$ & & \\
& & & 0.672 & 0.612 \\
1997 Log Population & & & $(4.09)$ & $(3.46)$ \\
& & & & -0.163 \\
Average Local & & -0.288 & & $(-0.91)$ \\
Overlap among & & $(-1.67)$ & & \\
Unrelated Stations & & & & \\
Number of Obs. & 237 & 237 & 237 \\
\hline
\end{tabular}

T-statistics in parentheses. 